\title{
Effect of CTAB coating on structural, magnetic and peroxidase mimic activity of ferric oxide nanoparticles
}

\author{
DIKSHIT GARG ${ }^{1, *}$, MANPREET KAUR $^{1}$, SUCHETA SHARMA $^{2}$ and VIBHA VERMA ${ }^{\mathbf{1}}$ \\ ${ }^{1}$ Department of Chemistry, Punjab Agricultural University, Ludhiana 141004, Punjab, India \\ ${ }^{2}$ Department of Biochemistry, Punjab Agricultural University, Ludhiana 141004, Punjab, India \\ *Author for correspondence (dikshitgarg762@gmail.com)
}

MS received 10 May 2018; accepted 20 August 2018; published online 4 October 2018

\begin{abstract}
In the present work, pristine and cetyl trimethyl ammonium bromide (CTAB)-coated ferric oxide nanoparticles (CTAB@ $@ \mathrm{Fe}_{2} \mathrm{O}_{3}$ NPs) were synthesized and studied as enzyme mimics. The w/w ratio of $\mathrm{Fe}_{2} \mathrm{O}_{3}$ to CTAB was varied as 1:1 and 1:2. Transmission electron microscopic analysis revealed that pristine NPs had an average size of $50 \mathrm{~nm}$, whereas the presence of CTAB resulted in the formation of nanorods with length of $130 \mathrm{~nm}$. BET studies confirmed enhancement of surface area on CTAB coating, which was maximum for w/w ratio 1:1. The synthesized pristine NPs and CTAB-coated NPs were evaluated for their peroxidase mimic activity using o-dianisidine dihydrochloride as substrate. Optimum $\mathrm{pH}$, temperature, substrate and NPs concentration for the reaction were $1,25^{\circ} \mathrm{C}, 0.16 \mathrm{mg} \mathrm{ml}^{-1}$ and $1 \mathrm{mg} \mathrm{ml}^{-1}$, respectively. Peroxidase mimic activity of CTAB $@ \mathrm{Fe}_{2} \mathrm{O}_{3} \mathrm{NPs}$ (w/w 1:1) was higher than that of pristine NPs. However, further increase in CTAB coating (w/w 1:2) resulted in lowering of peroxidase mimic activity. Kinetic analysis was carried out at optimized conditions; maximum velocity $\left(V_{\max }\right)$ and Michaelis constant $\left(K_{\mathrm{m}}\right)$ value of $\mathrm{CTAB} @ \mathrm{Fe}_{2} \mathrm{O}_{3} \mathrm{NPs}_{\mathrm{s}}$ at $1: 1$ w/w ratio were $7.69 \mathrm{mM}$ and $1.12 \mu \mathrm{mol} \mathrm{s}^{-1}$, respectively.
\end{abstract}

Keywords. Ferric oxide nanoparticles; peroxidase enzyme; enzyme mimic; CTAB.

\section{Introduction}

Artificial enzymes have been attracting the attention of researchers due to several disadvantages in the performance of natural enzymes such as rapid denaturation by environmental changes, which alter their structure and catalytic properties [1]. Preparation, purification and storage of natural enzymes are very difficult, expensive and time-consuming, which limits their widespread applications [2]. Artificial enzymes, on the contrary, have been explored because of their easy preparation, low-cost storage and purification processes [3]. Nanomaterials as enzyme mimics have become a growing area of research. Thus, it is crucial to look for stability, catalytic efficiency and enzyme mimic activity from the practical point of view. They have already gained several applications in the fields such as immunoassays, therapy, stem cell growth, pollutant removal and cancer diagnostics [4]. To date, several artificial enzymes have been reported to mimic natural analogues, including hydrolase, aldolase, nitrile hydratase, ligase, lipase, peroxidase and superoxide dismutase $[5,6]$.

A variety of nanostructures, including carbon materials [7-9], nanocomposites [10,11], noble metals [12,13] and metal oxides [14-16], have displayed peroxidase-like activity. Of late, magnetic nanoparticles (NPs) have become rapidly growing and most exciting areas for studying peroxidase mimic activity. $\mathrm{Fe}_{2} \mathrm{O}_{3}$ NPs are reported to exhibit enhanced peroxidase mimic activity as compared with natural horseradish peroxidase (HRP) [17]. These NPs have the ability of scavenging or generating reactive oxygen species that can be used to mimic the peroxidase activity of natural ones. Similar to HRP, $\mathrm{Fe}_{2} \mathrm{O}_{3}$ NPs catalyse the oxidation of various substrates such as 3,3,5,5,-tetramethylbenzidine (TMB), o-phenylenediamine (OPD), 3,3-diaminobenzidine (DAB) and o-dianisidine dihydrochloride. All substrates undergo differential colour change when catalytically oxidized on exposure to $\mathrm{Fe}_{2} \mathrm{O}_{3}$ NPs. To date, a number of peroxidase mimic NPs, including maghemite, magnetite and enzymes containing $\mathrm{Fe}^{2+}$ and $\mathrm{Fe}^{3+}$ in their reaction centre, have been explored [18-21].

Activity of $\mathrm{Fe}_{2} \mathrm{O}_{3}$ gets altered on coating. Citrate-capped $\mathrm{Fe}_{2} \mathrm{O}_{3}$ NPs $\left(\mathrm{N}_{\text {cit }}\right)$ showed higher turnover value as compared with caboxymethyl dextrane $\left(\mathrm{K}_{\mathrm{CMD}}\right)$-coated NPs with both TMB and ABTS [2,2'-azino-bis(3-ethylbenzothiazoline6-sulphonic acid)] as substrate. A possible reason for the low activity of $\mathrm{K}_{\mathrm{CMD}}$ was its thicker coating that resulted in the steric effects. On the other hand, glycerine-coated ferric oxide $\mathrm{NPs}\left(\mathrm{N}_{\mathrm{gly}}\right)$ displayed higher $K_{\text {cat }}$ value than polylysine-coated ferric oxide NPs ( $\left.\mathrm{N}_{\mathrm{PLL}}\right)$ towards TMB but displayed low $K_{\text {cat }}$ value towards ABTS. $\mathrm{N}_{\mathrm{PLL}}$ have a slightly higher positive charge present on their surface than $\mathrm{N}_{\mathrm{gly}}$, which affects the activity [22]. 
Several other NPs have been reported, such as $\mathrm{Fe}_{2} \mathrm{O}_{3}$ NPs coated with both high molecular mass and low molecular mass dextran [23-26], iron NPs coated with carboxyl dextran [27-29], silica-coated super-paramagnetic iron oxide NPs $[30,31]$ and non-stoichiometric super-paramagnetic $\mathrm{Fe}_{2} \mathrm{O}_{3}$ NPs coated with polyglucose orbital carboxymethyl ether [32]. Cetyl trimethyl ammonium bromide (CTAB) surfactant is mostly used in the preparation of NPs due to its property of controlling the shape and size of the particles [33,34]. To the best of our knowledge, peroxidase mimic activity of CTABcoated $\mathrm{Fe}_{2} \mathrm{O}_{3}$ NPs has not been reported. In the present work, cationic CTAB was chosen as surfactant for $\mathrm{Fe}_{2} \mathrm{O}_{3}$ NPs coating because it can interact with the negatively charged iron oxide NPs formed during co-precipitation. Effect of changing $\mathrm{CTAB}$ coating on the peroxidase mimic activity of $\mathrm{Fe}_{2} \mathrm{O}_{3} \mathrm{NPs}$ has also been studied using o-dianisidine dihydrochloride as substrate.

\section{Experimental}

\subsection{Synthesis and characterization}

All chemicals used, i.e., hydrogen peroxide $\left(\mathrm{H}_{2} \mathrm{O}_{2}-30 \%\right)$, $\mathrm{NH}_{4} \mathrm{OH}$ (wt. $25 \%$ ), CTAB $\left(\mathrm{C}_{19} \mathrm{H}_{42} \mathrm{BrN}\right)$, ferrous ammonium sulphate $\left[\left(\mathrm{NH}_{4}\right)_{2} \mathrm{Fe}\left(\mathrm{SO}_{4}\right)_{2} \cdot 6 \mathrm{H}_{2} \mathrm{O}\right]$, ammonium ferric sulphate $\left[\mathrm{NH}_{4} \mathrm{Fe}\left(\mathrm{SO}_{4}\right)_{2} \cdot 6 \mathrm{H}_{2} \mathrm{O}\right]$, o-dianisidine dihydrochloride $\left[\mathrm{C}_{14} \mathrm{H}_{18} \mathrm{Cl}_{2} \mathrm{~N}_{2} \mathrm{O}_{2}\right]$ were of analytical reagent grade. Pristine and CTAB-coated $\mathrm{Fe}_{2} \mathrm{O}_{3}$ NPs (with varying w/w ratio of $\mathrm{Fe}_{2} \mathrm{O}_{3}$ : CTAB, i.e., 1:1 and 1:2) were synthesized by coprecipitation method; these NPs were designated as F-1, F-2 and F-3, respectively. To synthesize pristine $\mathrm{Fe}_{2} \mathrm{O}_{3} \mathrm{NPs}$, $0.022 \mathrm{~mol}$ of $\left[\mathrm{NH}_{4} \mathrm{Fe}\left(\mathrm{SO}_{4}\right)_{2} \cdot 6 \mathrm{H}_{2} \mathrm{O}\right]$ and $0.0146 \mathrm{~mol}$ of $\left(\mathrm{NH}_{4}\right)_{2} \mathrm{Fe}\left(\mathrm{SO}_{4}\right)_{2} \cdot 6 \mathrm{H}_{2} \mathrm{O}$ were dissolved in $50 \mathrm{ml}$ de-ionized water with continuous stirring [35]. In order to form precipitates, $5 \mathrm{ml}$ ammonium hydroxide was added to this solution dropwise with vigorous stirring until the $\mathrm{pH}$ of the mixture reached up to 9 . This solution was further stirred for $45 \mathrm{~min}$ with continuous heating at $85^{\circ} \mathrm{C}$. Precipitates formed were separated by centrifugation. Filtrate was washed with ethanol followed by de-ionized water several times until the $\mathrm{pH}$ of the filtrate became 7. Filtrate was dried in an oven at $100^{\circ} \mathrm{C}$ for $8 \mathrm{~h}$. Similar method was employed for the synthesis of CTAB@ $\mathrm{Fe}_{2} \mathrm{O}_{3}$ NPs. During synthesis of $\mathrm{Fe}_{2} \mathrm{O}_{3}$ NPs, CTAB was added in w/w ratio of $1: 1$ and $1: 2$ in the reaction mixture and CTAB-coated $\mathrm{Fe}_{2} \mathrm{O}_{3}$ NPs were labelled as F-2 and F-3, respectively.

The Scherrer relationship was applied to find the average particle size:

$$
D=0.9 \lambda / \beta \cos \theta,
$$

where $\lambda$ represents wavelength of $\mathrm{X}$-ray $(1.54 \mathrm{~nm}), \beta$ represents full-width at half-maximum (FWHM) and $\theta$ is diffraction angle $\left(17.866^{\circ}\right)$. Details of techniques employed, viz., FT-IR, X-ray diffraction (XRD), scanning electron microscopy (SEM), transmission electron microscopy (TEM), VSM and BET analysis are described in the previous publication [36].

\subsection{Kinetic analysis}

Enzyme mimic activity of synthesized NPs was evaluated by the method of Shannon et al [37]; $\mathrm{pH}$ of the reaction mixture was varied from 1 to 10 using $0.1 \mathrm{~N} \mathrm{HCl}$ and $0.1 \mathrm{~N}$ $\mathrm{NaOH}$ to ascertain optimum $\mathrm{pH}$. Effect of catalyst dose, substrate concentration, temperature and contact time was studied to optimize the reaction conditions. Kinetic experiments were carried out under optimized conditions. The solution was analysed at $430 \mathrm{~nm}$ using a UV-vis spectrophotometer in time course mode for $3 \mathrm{~min}$, with a 30 -s time interval. The Lineweaver-Burk plot was employed for the calculation of Michaelis-Menten constant as follows:

$$
\frac{1}{v}=\frac{K_{\mathrm{m}}}{V_{\max }\left((1 /[\mathrm{S}])+\left(1 / K_{\mathrm{m}}\right)\right)} .
$$

Here, $v$ is initial velocity, $V_{\max }$ and $[\mathrm{S}]$ represent the maximum velocity of the reaction and substrate concentration, respectively, whereas $K_{\mathrm{m}}$ represents the MichaelisMenten constant, which is an indicator of enzyme affinity for its substrate. Smaller the value of $K_{\mathrm{m}}$, greater the affinity between enzyme and substrate.

\section{Characterization}

\subsection{Structural analysis}

The crystalline structure of F-1, F-2 and F-3 was identified by the XRD technique. Diffraction peaks in XRD (figure 1a) pattern of $\mathrm{Fe}_{2} \mathrm{O}_{3} \mathrm{NPs}$ were observed at $2 \theta=$ $20,30.39,35.73,43.42,53.81,57.39$ and $63.01^{\circ}$ with the inter-planar spacing of $0.29,0.25,0.20,0.17,0.16$ and $0.16 \mathrm{~nm}$, which were assigned to (111), (104), (110), (202), (116), (018) and (214) planes, respectively. These data matched with the values reported in literature for $\mathrm{Fe}_{2} \mathrm{O}_{3}$ NPs [38]. In F-2 and F-3, the peaks were broadened and increase in FWHM was observed, which confirmed decrease in average particle size as compared with bare $\mathrm{Fe}_{2} \mathrm{O}_{3}$ NPs. These results suggested that the inter-planar spacing increased, which led to the decrease in particle size.

The binding of CTAB to the $\mathrm{Fe}_{2} \mathrm{O}_{3}$ NPs was investigated by FT-IR spectra. Figure $1 \mathrm{~b}$ presents the IR spectra of pristine and CTAB-coated $\mathrm{Fe}_{2} \mathrm{O}_{3}$ NPs. In pristine $\mathrm{Fe}_{2} \mathrm{O}_{3}$ NPs, the bands at 1582 and $3172 \mathrm{~cm}^{-1}$ are attributed to $\mathrm{O}-\mathrm{H}$ bending and stretching vibrations, respectively, which is due to the water molecules adsorbed onto the surface of bare NPs. Absorption bands in the region of $415-618 \mathrm{~cm}^{-1}$ are assigned to $\mathrm{Fe}-\mathrm{O}$ stretching vibrations 


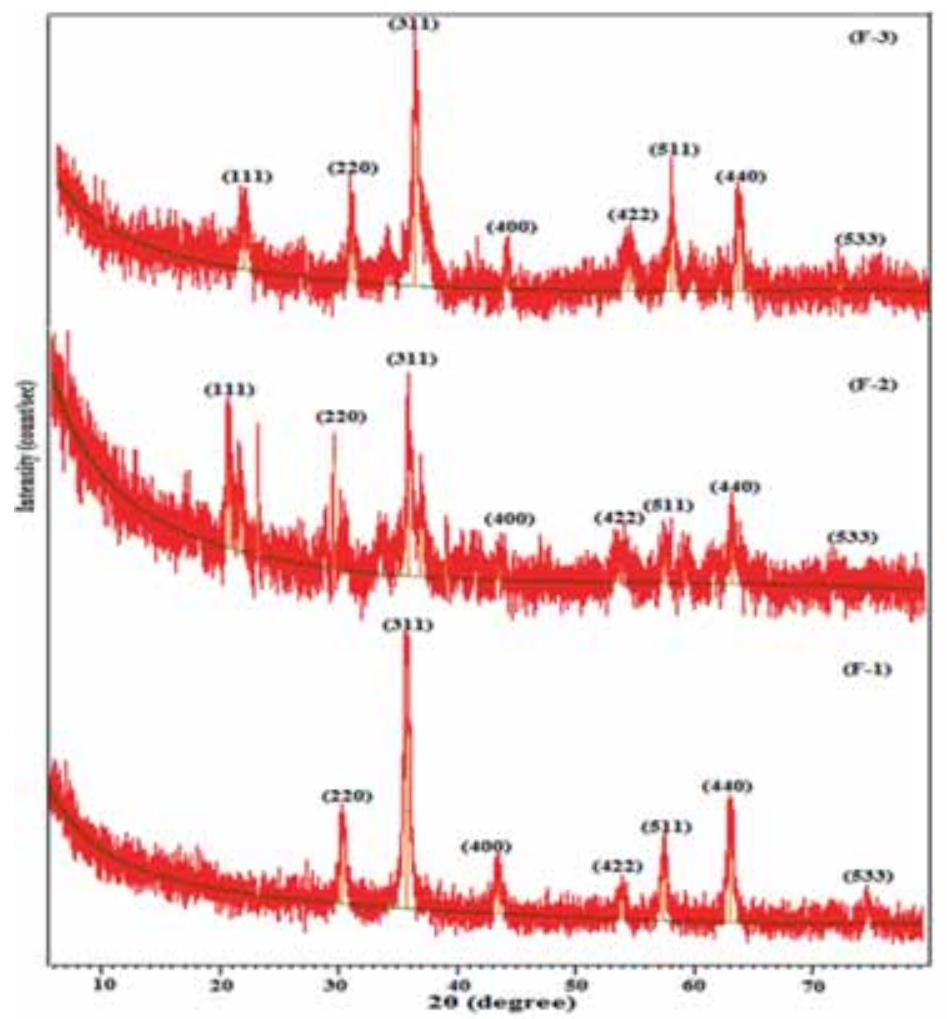

(a)

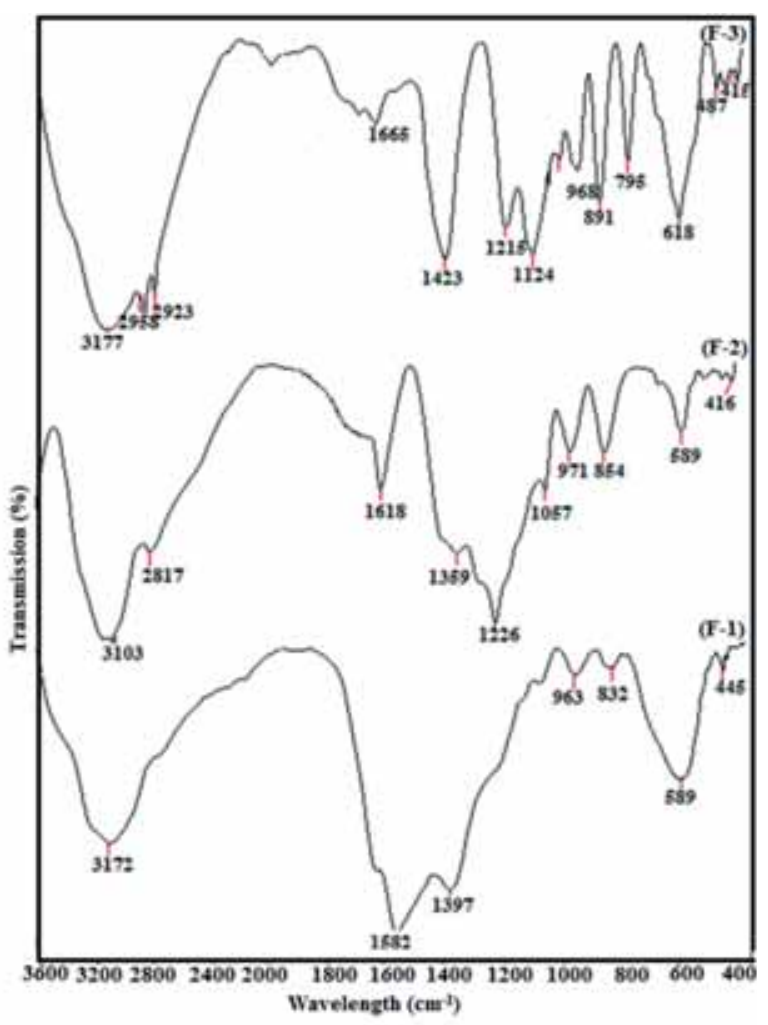

(b)

Figure 1. (a) XRD patterns and (b) FT-IR graphs of bare and CTAB-coated $\mathrm{Fe}_{2} \mathrm{O}_{3} \mathrm{NPs}$.

[39]. The absorption bands at $445 \mathrm{~cm}^{-1}$ in bare NPs and $416,487 \mathrm{~cm}^{-1}$ in the surfactant-coated NPs are due to $\mathrm{Fe}-\mathrm{O}$ bond vibrations in octahedral sites. The bands at $589 \mathrm{~cm}^{-1}$ in bare NPs and at 586, $618 \mathrm{~cm}^{-1}$ in CTAB-coated NPs correspond to $\mathrm{Fe}-\mathrm{O}$ bond vibrations in the tetrahedral sites. In case of bare and CTAB-coated $\mathrm{Fe}_{2} \mathrm{O}_{3} \mathrm{NPs}$, the bands at 3172,3103 and $3177 \mathrm{~cm}^{-1}$ correspond to O-H stretching vibrations. Furthermore, the bands at 1124 , 1215 and $1226 \mathrm{~cm}^{-1}$ in CTAB-coated NPs correspond to $\mathrm{C}-\mathrm{N}$ bond stretching. The bands at 1359 and $1423 \mathrm{~cm}^{-1}$ are due to the residual ammonia used at the time of NPs preparation.

Furthermore, the bands at 1665 and $1618 \mathrm{~cm}^{-1}$ correspond to $\mathrm{N}-\mathrm{H}$ bending vibrations, and the bands at $3177 \mathrm{~cm}^{-1}$ in coated NPs correspond to stretching vibrations of $\mathrm{O}-\mathrm{H}$ bonds. The bands at $968,891,971$ and $854 \mathrm{~cm}^{-1}$ in both types of CTAB-coated NPs are due to the presence of tertiary amine. The bands over $3000-3600 \mathrm{~cm}^{-1}$ are attributed to reduced amount of water present in the samples. The bands at $795 \mathrm{~cm}^{-1}$ correspond to $\mathrm{C}-\mathrm{H}$ bending of long alkane chain present in CTAB. Furthermore, additional bands in the range of $2800-3000 \mathrm{~cm}^{-1}$ in coated NPs are attributed to the stretching vibrations of $\mathrm{C}-\mathrm{H}$ bonds of the saturated alkane [40]. In addition, a small shift in peaks was seen on coating $\mathrm{Fe}_{2} \mathrm{O}_{3}$ NPs with CATB, which is due to the change in environment of bare NPs.

\subsection{Morphological studies}

SEM and TEM were used to study the surface morphology and particle size distribution of synthesized pristine and CTABcoated NPs. SEM micrographs of pristine NPs (figure 2a) clearly depict their porous surface, whereas CTAB-coated NPs, F-2 and F-3 (figure 2b and c), have somewhat more porous structure as compared with $\mathrm{F}-1$ due to the immobilization of CTAB onto the surface of $\mathrm{Fe}_{2} \mathrm{O}_{3}$ NPs. TEM images (figure 3) reveal shape and morphology of NPs. F-1 appeared to be spherical and somewhat agglomerated due to the strong dipole-dipole magnetic interactions between NPs. However, rods were formed when $\mathrm{Fe}_{2} \mathrm{O}_{3}$ NPs were synthesized in the presence of CTAB due to the adsorption of CTAB on the surface of NPs, thus preventing their agglomeration due to the repulsion between the similar charged ions of CTAB. Particle size of $\mathrm{Fe}_{2} \mathrm{O}_{3}$ NPs also decreased on coating CTAB.

A similar reason for the rod formation was given by Chen et al [41] in their study when $\mathrm{Fe}_{3} \mathrm{O}_{4} \mathrm{NPs}$ were treated with $\mathrm{FeCl}_{3}$ solution. $\mathrm{Fe}^{3+}$ ions were absorbed on the surface of NPs due to the common ion effect. This scheme was co-ordinated with our approach for the CTABcoated $\mathrm{Fe}_{2} \mathrm{O}_{3}$ NPs. Another approach towards the formation of rod-shaped NPs was reported by Zhao and Nan [40]. The stability arises from the fact that a certain amount 


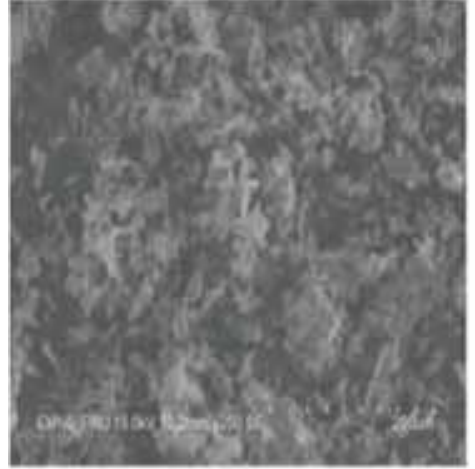

(a)

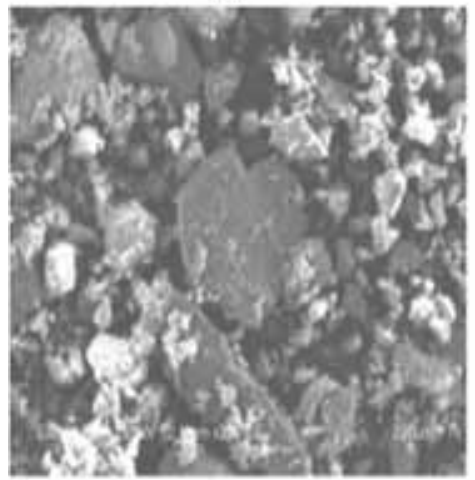

(b)

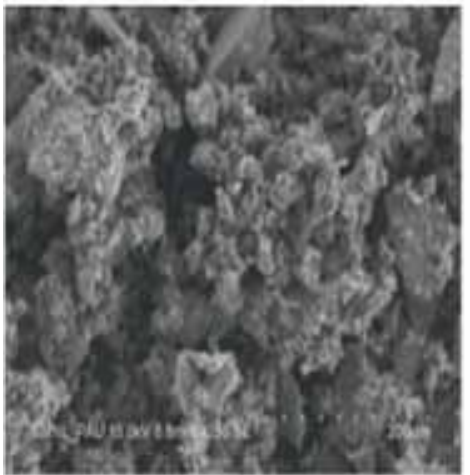

(c)
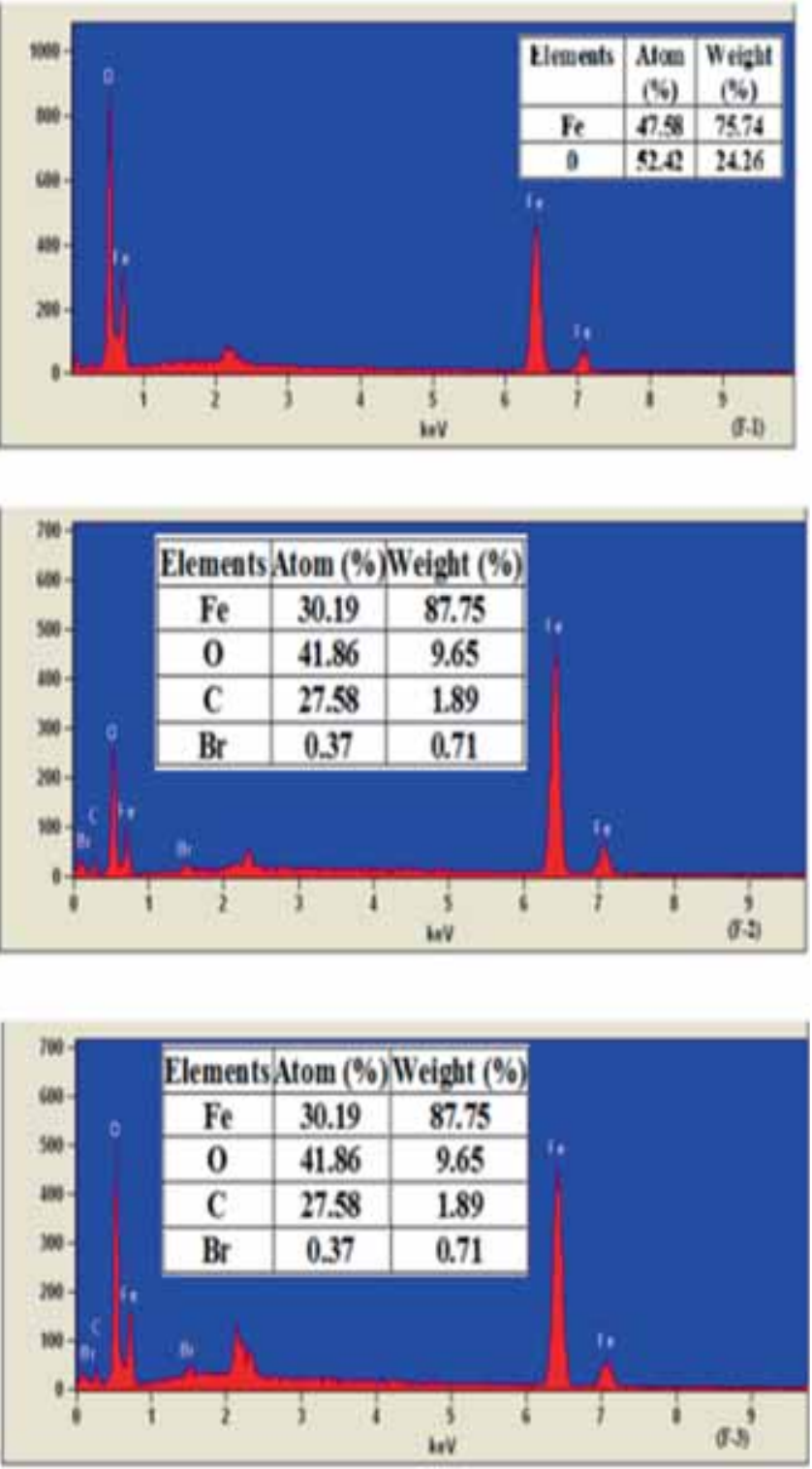

Figure 2. SEM-EDX images of (a) F-1, (b) F-2 and (c) F-3.

of space was occupied by the polymers coated on the surface of NPs. The space was compressed when the NPs came too close, thus triggering the formation of rod-shaped NPs.

Nitrogen adsoprtion-desorption studies of pristine and CTAB-coated $\mathrm{Fe}_{2} \mathrm{O}_{3}$ NPs were carried using BET analysis to characterize the surface properties of synthesized NPs. Figure 4 displays nitrogen sorption isotherms and pore size distribution curves. IUPAC classification designates these isotherms as type IV, which represents mesoporous structure with comparatively broad hysteresis loop belonging to $\mathrm{H} 1$ type. The meso-porosity of the F-2 increased with increase in the pore volume as compared with bare ones but decreased on further increase in coating. The BET surface area of F-2 and F-3 NPs was 69.174 and $49.072 \mathrm{~m}^{2} \mathrm{~g}^{-1}$, respectively (table 1). Lower surface area of F-1 was due to the strong Van der Walls forces of interaction among particles, which led to their agglomeration.

\subsection{Magnetic studies}

Hysteresis loop depicted the effect of change in magnetic field on magnetization and magnetic flux of synthesized NPs. Variation in magnetic character of the NPs on coating with CTAB was also seen from the loop (figure 5) and the magnetic parameters of the synthesized NPs (table 2). The saturation 

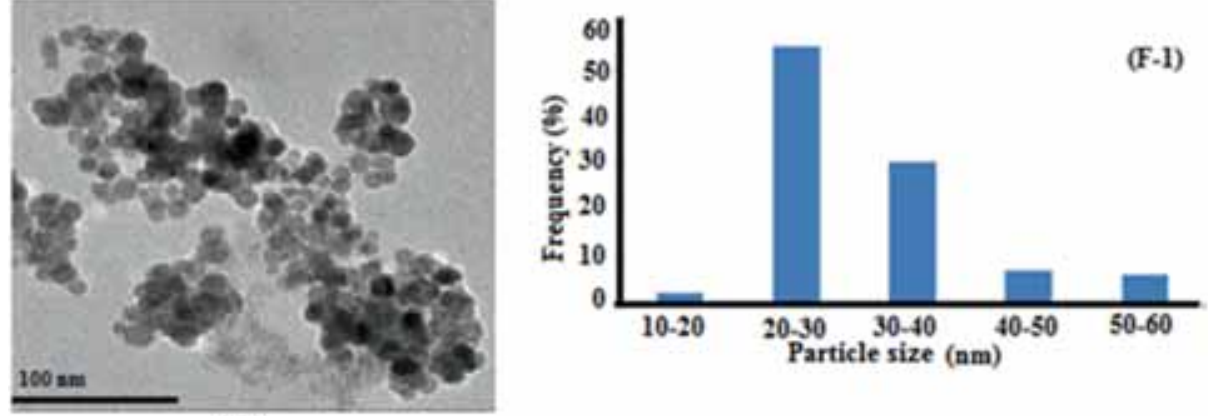

(a)
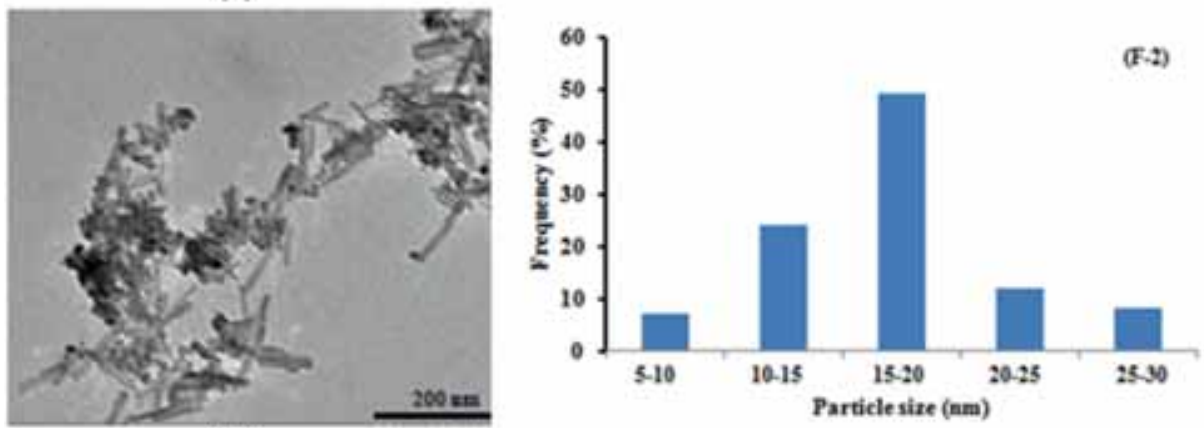

(b)
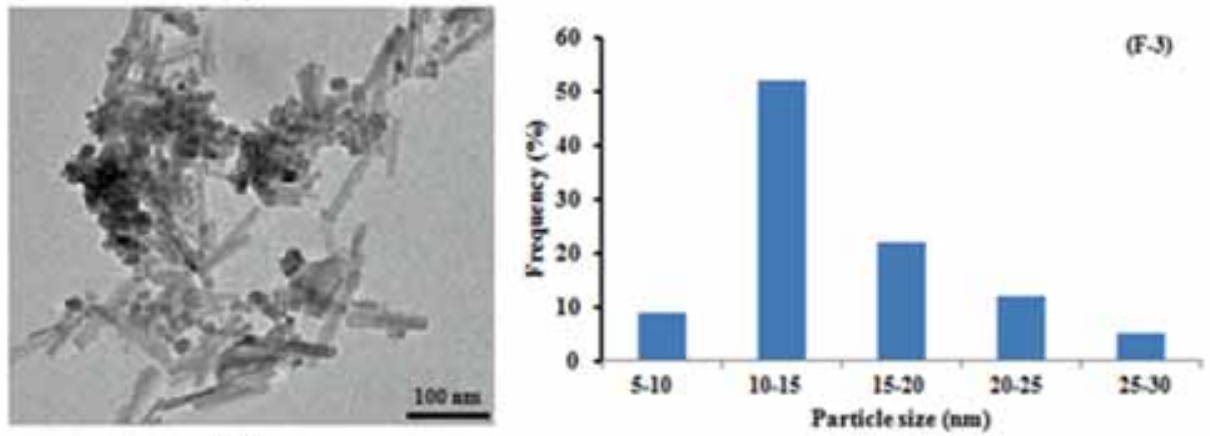

(c)
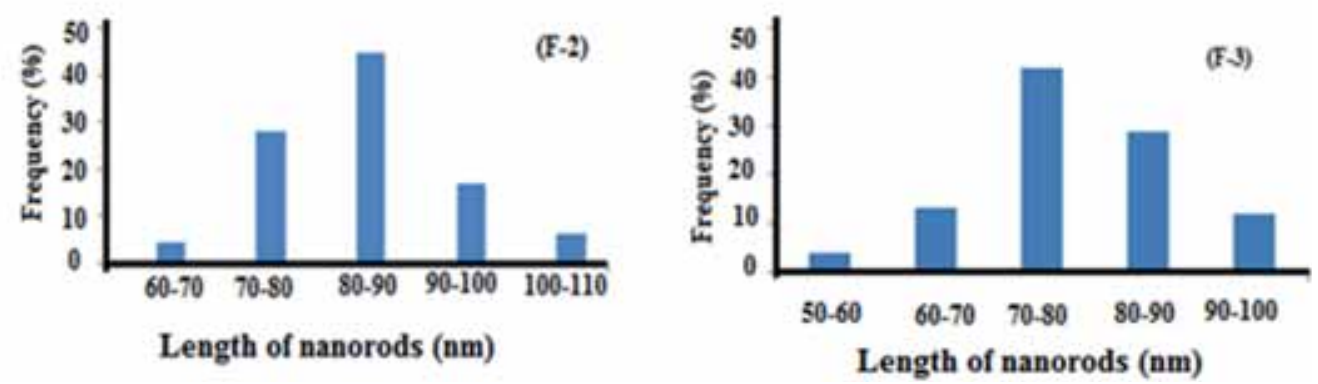

Figure 3. TEM images and histograms of (a) pristine NPs (F-1). CTAB $@ \mathrm{Fe}_{2} \mathrm{O}_{3}$ with (b) 1:1 (F-2) and (c) 2:1 (F-3) ratio.

magnetization $\left(M_{\mathrm{s}}\right)$ of F-2 and F-3 NPs was decreased due to coating of non-magnetic CTAB on the surface of $\mathrm{Fe}_{2} \mathrm{O}_{3}$ NPs. Low coercivity values of these NPs also categorized them as soft ferromagnetic material. Narrow hysteresis loops along with low coercivity range of NPs from 12.98 to $54.05 \mathrm{O}_{\mathrm{e}}$ show that these NPs can be easily demagnetized [42].

\section{Enzyme mimic activity of pristine and CTAB-coated $\mathrm{Fe}_{2} \mathrm{O}_{3} \mathrm{NPs}$}

The peroxidase-like activity of synthesized NPs with o-dianisidine dihydrochloride as substrate was studied in the presence of $\mathrm{H}_{2} \mathrm{O}_{2}$. o-dianisidine dihydrochloride possessed opposite charge character than that of synthesized 


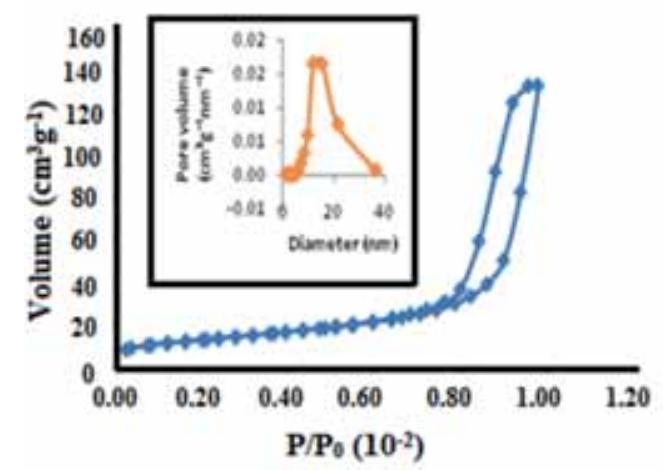

(a)

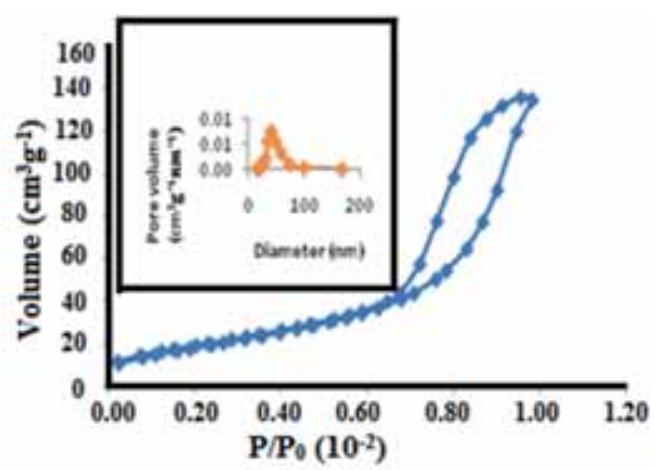

(b)

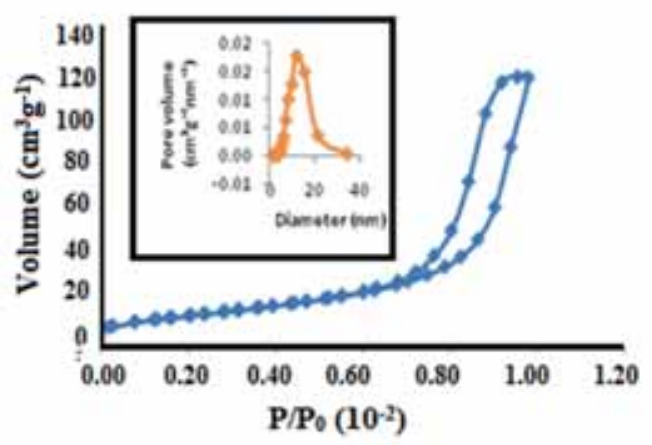

(c)

Figure 4. $\mathrm{N}_{2}$ adsorption isotherms and corresponding pore size distribution (inset) of pristine NPs (F-1) and CTAB-coated $\mathrm{Fe}_{2} \mathrm{O}_{3}$ NPs (F-2 and F-3).

Table 1. BET surface area parameters of F-1, F-2 and F-3 NPs.

\begin{tabular}{lccc}
\hline Compound & $\begin{array}{c}\text { Surface area } \\
\left(\mathrm{m}^{2} \mathrm{~g}^{-1}\right)\end{array}$ & $\begin{array}{c}\text { Pore volume } \\
\left(\mathrm{cm}^{3} \mathrm{~g}^{-1}\right)\end{array}$ & $\begin{array}{c}\text { Pore diameter } \\
(\mathrm{nm})\end{array}$ \\
\hline F-1 & 45.374 & 0.209 & 11.971 \\
F-2 & 69.174 & 0.218 & 41.335 \\
F-3 & 49.072 & 0.188 & 12.038 \\
\hline
\end{tabular}

NPs, thus increasing its ability to interact with NPs [40]. Pristine and CTAB-coated $\mathrm{Fe}_{2} \mathrm{O}_{3}$ NPs could catalyse the oxidation of o-dianisidine dihydrochloride by $\mathrm{H}_{2} \mathrm{O}_{2}$, producing a dark brown colour. The colour of the CTAB @ $\mathrm{Fe}_{2} \mathrm{O}_{3} \mathrm{NPs}-$ $\mathrm{H}_{2} \mathrm{O}_{2}$-substrate system showed more absorbance than that of the $\mathrm{H}_{2} \mathrm{O}_{2}$-substrate system, whereas CTAB @ $\mathrm{Fe}_{2} \mathrm{O}_{3} \mathrm{NPs}-$ substrate system did not produce any colour (as shown in the inset of figure 6). It indicates that CTAB @ $\mathrm{Fe}_{2} \mathrm{O}_{3}$ NPs possess peroxidase-like activity in the presence of $\mathrm{H}_{2} \mathrm{O}_{2}$. Also, activity gets enhanced on increasing the substrate concentration because more substrate molecules starts interacting with $\mathrm{H}_{2} \mathrm{O}_{2}$, thus producing more oxidized product.

The probable mechanism for peroxidase-like activity of CTAB@ $@ \mathrm{Fe}_{2} \mathrm{O}_{3}$ NPs $(1: 1)$ is shown in scheme 1. These NPs catalysed the decomposition of $\mathrm{H}_{2} \mathrm{O}_{2}$ to produce $\mathrm{OH}$ radicals,

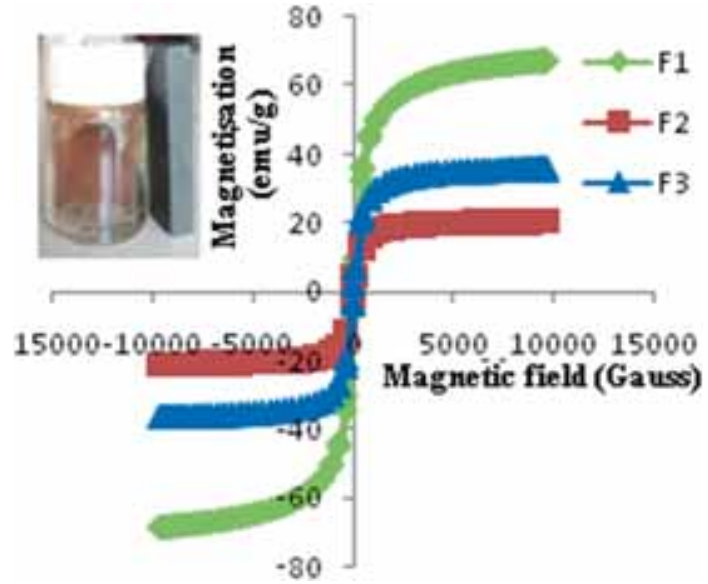

Figure 5. Hysteresis loop of F-1, F-2 and F-3 NPs.

which furthur oxidized o-dianisidine dihydrochloride, producing dark brown oxidized product.

\subsection{Effect of temperature, contact time and $\mathrm{pH}$ on peroxidase mimic activity}

The effect of temperature, contact time and $\mathrm{pH}$ on peroxidase mimic activity in the reaction mixture was evaluated. 
Table 2. Saturation magnetization, retentivity and coercivity of as-synthesized NPs.

\begin{tabular}{lccc}
\hline NPs & $\begin{array}{c}\text { Saturation magnetization } \\
M_{\mathrm{S}}\left(\mathrm{emu} \mathrm{g}^{-1}\right)\end{array}$ & $\begin{array}{c}\text { Retentivity } \\
\left(\mathrm{emu} \mathrm{g}^{-1}\right)\end{array}$ & $\begin{array}{c}\text { Coercivity } \\
H_{\mathrm{c}}\left(\mathrm{O}_{\mathrm{e}}\right)\end{array}$ \\
\hline F-1 & 67.16 & 482 & 54.05 \\
F-2 & 20.12 & 414 & 29.59 \\
F-3 & 35.65 & 60 & 12.98 \\
\hline
\end{tabular}

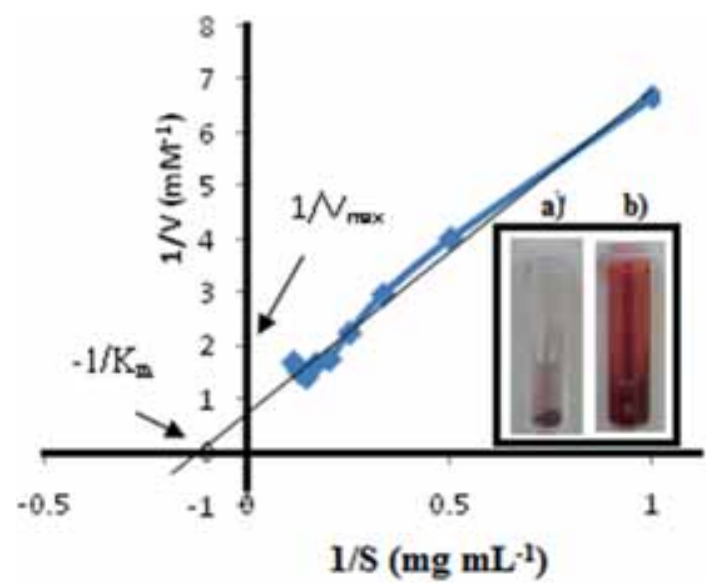

Figure 6. Line-weaver-Burk plot of F-2 NPs (inset-peroxidaselike activity of synthesized NPs: (a) CTAB@ $\mathrm{Fe}_{2} \mathrm{O}_{3}$ NPs-substrate system and (b) CTAB@ $\mathrm{Fe}_{2} \mathrm{O}_{3} \mathrm{NPs}$-substrate system- $\mathrm{H}_{2} \mathrm{O}_{2}$ system).
Peroxidase mimic activity of NPs was observed by varying the $\mathrm{pH}$ of the reaction mixture from 1 to 10 (figure 7a). The synthesized NPs showed the highest activity at $\mathrm{pH} 1$ and activity decreased on further increasing $\mathrm{pH}$ of the reaction mixture. At low $\mathrm{pH}$, the presence of $\mathrm{H}^{+}$facilitates the decomposition of $\mathrm{H}_{2} \mathrm{O}_{2}$, thus increasing the rate of reaction. The variation in temperature from 10 to $45^{\circ} \mathrm{C}$ resulted in increase in the rate of reaction up to $25^{\circ} \mathrm{C}$ and later reaction rate showed a decreasing trend, indicating that $25^{\circ} \mathrm{C}$ was the optimum temperature for peroxidase mimic activity of NPs. The decrease in activity at high temperature can be explained on the basis of reaction mechanism as given in scheme 1 . The first step involves the adsorption of $\mathrm{H}_{2} \mathrm{O}_{2}$ on the surface of NPs followed by the cleavage of $\mathrm{H}_{2} \mathrm{O}_{2}$ to liberate $\mathrm{OH}$ radicals. At high temperature the adsorptive interactions between $\mathrm{H}_{2} \mathrm{O}_{2}$ and NPs slowed down, leading to decrease in activity [43].

Similarly, concentration of substrate and NPs was optimized by varying their content. Optimum concentration of the substrate was $0.16 \mathrm{mg} \mathrm{ml}^{-1}$ and that for F-2 NPs was $1.0 \mathrm{mg} \mathrm{ml}^{-1}$ using $0.1 \mathrm{~N} \mathrm{HCl}$ as solvent (figure 8a). The absorbance of the oxidized product increased with increase in the concentration of F-2 NPs till $1.0 \mathrm{mg} \mathrm{ml}^{-1}$ and afterwards it decreased. This was attributed to the aggregation of these particles, which decreased the surface/volume ratio and hence decreased the enzyme mimic activity. Under optimized conditions, peroxidase mimic activities of F-1, F-2 and F-3 were compared. F-2 displayed the highest peroxidase mimic activity followed by F-1 and F-3 (figure 8b). These results suggested that at lower $\mathrm{CTAB}$ concentration, activity was increased due to smaller particle size and lesser agglomeration

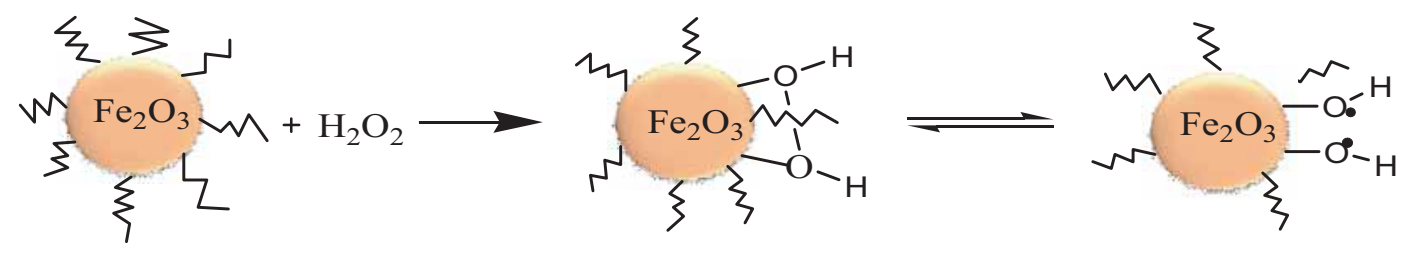<smiles>COc1cc(-c2ccc(N)c(OC)c2)ccc1N</smiles><smiles>COc1cc(-c2ccc(N=Nc3ccc(-c4ccc(N)c(OC)c4)cc3OC)c(O)c2)ccc1N</smiles>

Scheme 1. The mechanism of mimic activity of CTAB @ $\mathrm{Fe}_{2} \mathrm{O}_{3}$ NPs. 


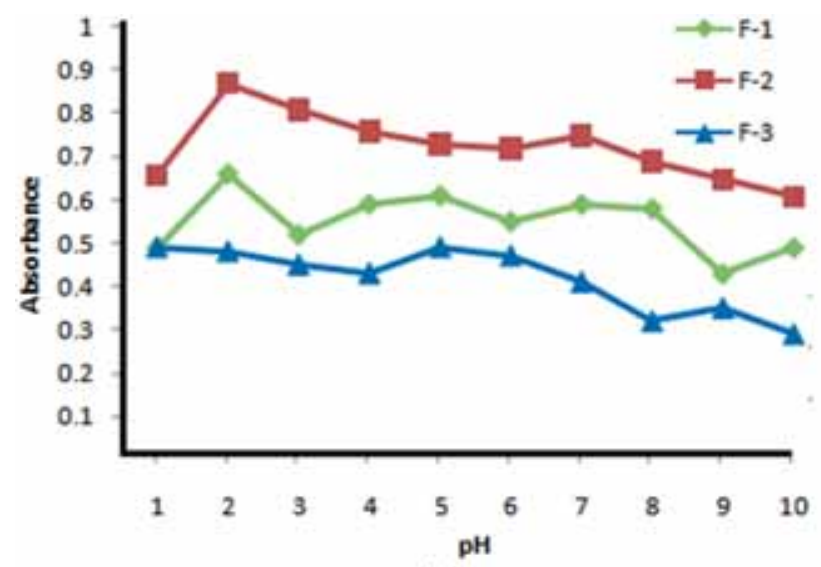

(a)

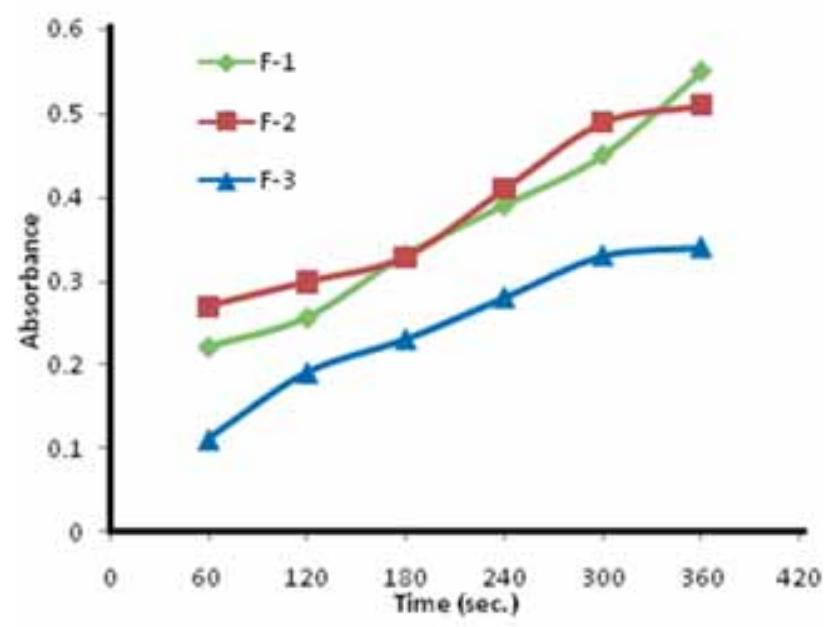

(b)

Figure 7. (a) Effect of $\mathrm{pH}$ on absorbance of solution in the presence of pristine (F-1) and CTAB-coated NPs (F-2 and F-3). (b) Effect of time on absorbance of solution using pristine (F-1) and CTAB-coated NPs (F-2 and F-3).

of NPs, which resulted in greater interaction with substrate. However, at higher CTAB concentration, decrease in peroxidase mimic activity was observed due to steric hindrance by CTAB molecules. The lower surface area of F-3 NPs as compared with F-2 NPs (as confirmed by BET analysis) decreased the number of active sites, thus lowering its interaction with the substrate, and diminished its enzyme mimic activity.

Higher peroxidase mimic activity for the CTAB @ $\mathrm{Fe}_{2} \mathrm{O}_{3}$ NPs was due to the coating, which increased surface area of $\mathrm{Fe}_{2} \mathrm{O}_{3}$ NPs [44]. Thus, more number of substrate molecules attached to the surface of catalyst due to increase in active sites, which increased turn over number, thus resulting in increased rate of reaction. Another reason for the activity of F-2 NPs was the presence of CTAB, which prevented particles agglomeration, due to which surface of the particles remained free for the substrate to interact. $\mathrm{Fe}_{2} \mathrm{O}_{3}$ NPs with higher $\mathrm{CTAB}$ concentration $(1: 2)$ led to decrease in activity

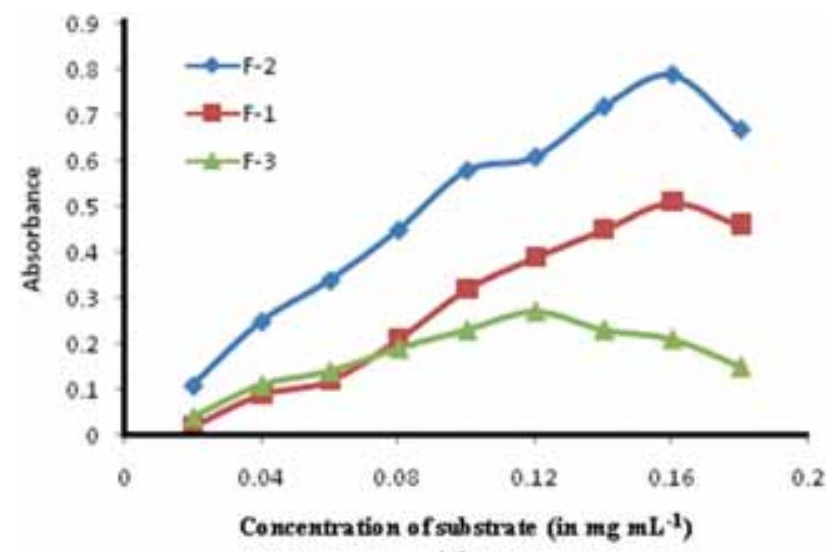

(a)

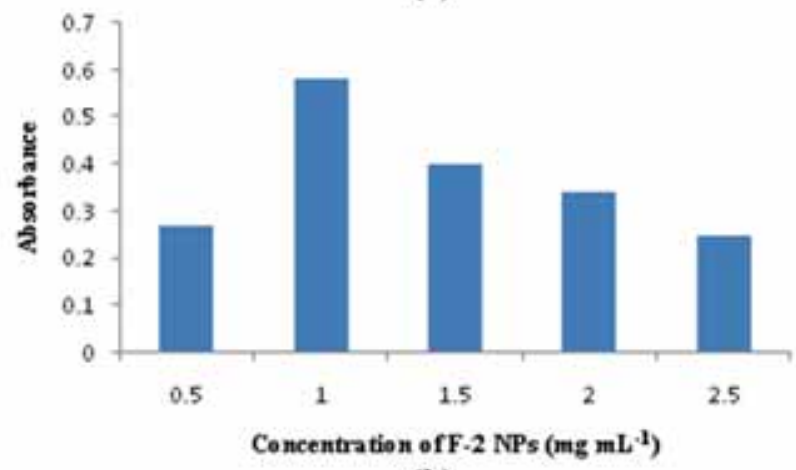

(b)

Figure 8. (a) Effect of substrate concentration on the absorbance in the presence of pristine (F-1) and CTAB @ $\mathrm{Fe}_{2} \mathrm{O}_{3}$ NPS (F-2 and F-3). (b) Graph showing optimized concentration of F-2 NPs.

due to steric hindrance, which decreased the surface area and thus number of active sites.

\subsection{Kinetic analysis}

Kinetic analysis was performed for the NPs, showing maximum peroxidase mimic activity, i.e., for F-2 NPs. From the Lineweaver-Burk plot (figure 6), the calculated $K_{\mathrm{m}}$ and $V_{\max }$ values of F-2 NPs are $7.69 \mathrm{mM}$ and $1.12 \mu \mathrm{mol} \mathrm{s}{ }^{-1}$, respectively. Savitsky et al [45] also studied the kinetic analysis of o-dianisidine oxidation using free and antibody complexes of iron(11l) coproporphyrin as peroxidase mimic. The $K_{\mathrm{m}}$ obtained for various complexes are in the range $0.53-5.9 \times 10^{6} \mathrm{M}$, whereas in the present study the $K_{\mathrm{m}}$ value is much lower, which confirms higher affinity of CTAB@ $\mathrm{Fe}_{2} \mathrm{O}_{3}$ NPs for the substrate. Lower value of $K_{\mathrm{m}}$ is an essential parameter for potential activity of enzyme mimics. Thus, kinetic studies authenticated the promising peroxidase mimic activity of $\mathrm{CTAB} @ \mathrm{Fe}_{2} \mathrm{O}_{3}$ NPs having w/w ratio 1:1.

\section{Conclusion}

We have synthesized pristine and CTAB-coated ferric oxide NPs (CTAB@ $\mathrm{Fe}_{2} \mathrm{O}_{3}$ NPs) by co-precipitation method and 
compared their peroxidase mimic activity. Results showed that $\mathrm{Fe}_{2} \mathrm{O}_{3}$ NPs synthesized in the presence of CTAB having $\mathrm{w} / \mathrm{w}$ ratio of 1:1 displayed higher peroxidase mimic activity, which was correlated with the higher surface area of the NPs. Further increase in CTAB concentration resulted in decrease in activity due to steric hindrance by the CTAB molecules adhering on the surface of NPs. CTAB@ $\mathrm{Fe}_{2} \mathrm{O}_{3} \mathrm{NPs}$ as peroxidase mimic showed promising properties, viz., easy preparation, storage, reusability, stability, dispersibility and easy separation, as compared with natural enzymes. They can be explored for varied applications as an economically viable substitute to peroxidase enzyme in various practical bio-medical applications such as biosensors for the detection of hydrogen peroxide in various commodities and glucose level in blood.

\section{Acknowledgements}

We are grateful to EMN Lab of Punjab Agricultural University, Ludhiana, for SEM and TEM recordings.

\section{References}

[1] Shoji E and Freund M S 2001 J. Am. Chem. Soc. 1233383

[2] Breslow R 1995 Acc. Chem. Res. 28146

[3] Wei H and Wang E 2013 Chem. Soc. Rev. 426060

[4] Colombo M, Carregal R S, Casula M F, Gutierrez L, Morales M P, Bohm I B et al 2012 Chem. Soc. Rev. 414306

[5] Chen W, Chen J, Feng Y B, Hong L, Chen Q Y, Wu L F et al 2012 Analyst 1371706

[6] Chen Z, Yin J J, Zhou Y T, Zhang Y, Song L, Song M et al 2012 ACS Nano 64001

[7] Cui R, Han Z and Zhu J J 2011 Chem. Eur. J. 179377

[8] Song Y, Qu K, Zhao C, Ren J and Qu X 2010 Adv. Mater. 22 2206

[9] Zheng A X, Cong Z X, Wang J R, Li J, Yang H H and Chen G N 2013 Biosens. Bioelectron. 49519

[10] Bi S, Zhao T, Jia X and He P 2014 Biosens. Bioelectron. 57 110

[11] Xing Z, Tian J, Asiri A M, Qusti A H, Al Youbi A O and Sun X 2014 Biosens. Bioelectron. 52452

[12] Jiang H, Chen Z, Cao H and Huang Y 2012 Analyst 137 5560

[13] Jv Y, Li B and Cao R 2010 Chem. Commun. 468017

[14] Andre R, Natalio F, Humanes M, Leppin J, Heinze K, Wever R et al 2011 Adv. Funct. Mater. 21501

[15] Chen W, Chen J, Liu A L, Wang L M, Li G W and Lin X H 2011 Chem. Cat. Chem. 31151

[16] Mu J, Wang Y, Zhao M and Zhang L 2012 Chem. Commun. 482540
[17] Gao L Z, Zhuang J, Nie L, Zhang J B, Zhang Y, Gu N et al 2007 Nat. Nanotechnol. 2577

[18] Henriksen A, Smith A T and Gajhede M 1999 J. Biol. Chem. 27435005

[19] Kvaratskhelia M, Winkel C and Thorneley R N F 1997 Plant Physiol. 1141237

[20] Kariya K, Lee E, Hirouchi M, Hosokawa M and Sayo H 1987 Biochim. Biophys. Acta 91195

[21] Hartert M M, Bourgeois E, Grülke S, Dupont G D, Caudron I, Deby C et al 1998 Can. J. Vet. Res. 62127

[22] Yu F, Huang Y, Cole A J and Yang V C 2009 Biomaterials 30 4716

[23] Clement O, Siauve N, Cuenod C A and Frija G 1998 Top. Magn. Reson. Imaging 9167

[24] Johnson L, Pinder S E and Douek M 2013 Histopathology 62 481

[25] Kernstine K H, Stanford W and Mullan B F 1999 Ann. Thorac. Surg. 681022

[26] Harisinghani M G, Saini S, Hahn P F, Weissleder R and Mueller P R 1998 Acad. Radiol. 5167

[27] Reimer P and Balzer T 2003 Eur. Radiol. 131266

[28] Vogl T J, Hammersting 1 R and Schwarz W 1996 Invest. Radiol. 31696

[29] Reimer P, Rummeny E J and Daldrup H E 1995 Radiology 195 489

[30] Bonnemain B 1998 J. Drug Target. 6167

[31] Campbell J L, Arora J, Cowell S F, Garg A, Eu P, Bhargava S $\mathrm{K}$ et al 2011 PLoS One 621857

[32] Bullivant J P, Zhao S, Willenberg B J, Kozissnik B, Batich C D and Dobson J 2013 Int. J. Mol. Sci. 1417501

[33] Zhang Y, Xu D, Li W, Yu J and Chen Y 2012 J. Nanomater. 20121

[34] Qiu Y, Liu Y, Wang L, Xu L, Bai R, Ji Y et al 2010 Biomaterials 317606

[35] Deng J H, Zhang X R, Zeng G M, Gong J L, Niu Q Y and Liang J 2013 Chem. Eng. J. 226189

[36] Grewal J K and Kaur M 2017 Ceram. Int. 4316611

[37] Shannon L M, Kay E and Lew J Y 1966 J. Biol. Chem. 241 2166

[38] Uzunov I and Aleksandrova A 2002 Chem. Inorg. 62 195

[39] Hoan N T V, Thu N T A, Duc H V, Cuong N D, Khieu D Q and Vo V 2016 J. Chem. 20161

[40] Zhao B and Nan Z 2011 Nanoscale Res. Lett. 61

[41] Chen A, Wang H, Zhao B and Li X 2003 Synth. Met. 139 411

[42] Ubhi M K, Kaur M, Singh D and Granchee J M 2017 Pure Appl. Chem. 11247

[43] Johnson B B 1990 Environ. Sci. Technol. 24112

[44] Cai S, Jia X, Han Q, Yan X, Yang R and Wang C 2017 Nano Res. 102056

[45] Savitsky A P, Nelen M I, Yatsmirsky A K, Demcheva M V, Ponomarev G V and Nikov I V 1994 Appl. Biochem. Biotechnol. 47317 